\title{
Language Identity as a Unifying Identity: Linguistic, Ethnopolitical and International Legal Aspects
}

Maxim Ivanovich Tsapko, ${ }^{+*}$ Fedor Ivanovich Valyarovskiy, ${ }^{\dagger}$ Elvira Tagirovna Maiboroda, ${ }^{\top}$ Evgeniia Nikolaevna Khusainova, '̄and Oxana Olegovna Varnavskaya ${ }^{\top}$

\section{Abstract}

The article is devoted to the problem of constructing a unifying identity through the commonality of language as an alternative to the concepts and practices most widely spread in the modern world, which are understood as the construction of a single ethnic identity (including the concepts of ethnonation and ethnonationalism), as well as the construction of general civil identity and "civil" nation. The primary attention is paid to the methodology of ethnology and social sciences in general, as well as to the scientific grounds and methods of the construction of a unifying identity through language. The evolution of methods of social sciences, changes in paradigms in ethnology, some linguistic theories in the problematic area of interdisciplinary research relevant to the issues of linguistic identity are considered. The international legal aspects of an ethnos are also considered; the inseparable connection between the phenomena of ethnicity, an ethnos and collective rights of an individual, on the one hand, and the phenomenon of native language and collective rights as one of the formats of existence and exercising personal rights and freedoms is postulated. The conclusion is made about the possibility, advantages, and potential social stability of the construction of a unifying identity that harmonises ethnic relationships through language identity.

Keywords: Identity, Ethnos, Ethnicity, Language, Human Rights

\footnotetext{
+ Pyatigorsk State University, 357500, Russian Federation, Pyatigorsk, Kalinina Street, 9. Email: tsapko-m@bk.ru

${ }^{*}$ Corresponding Author

${ }^{\top}$ North-Caucasian Federal University, 355009, Russian Federation, Stavropol, Street Pushkina, 1

(C) 2018 Tsapko et al. This is an Open Access article distributed under the terms of the Creative Commons Attribution License (http://creativecommons.org/licenses/by/2.0), which permits unrestricted use, distribution, and reproduction in any medium, provided the original work is properly cited.
} 


\section{Introduction}

Against the large-scale ethnisation of public life, ethnicity becomes an essential sociopolitical resource and status marker. The proposed Russian projects of harmonisation of ethnic relations, ethnicity depoliticisation and the construction of the space for interethnic dialogue are based, to a large extent, on the development of supra-group (macrosocial) identity as a unifying identity "layer" in social relations. The most wellknown Russian projects of the last decades have been suggested based on the phenomenon of "general civil" identity: from a conditional project "Russians" to the next search for the "Russian nation", which is expected to reproduce the motive of eternal return to the construction of a civil nation in a multinational state (Tishkov, 2017). Thus, the modern attempts to build a supragroup identity in Russia in many ways repeat the Soviet project of the supragroup identity"Soviet people". It is a construct of a multicultural society that relies on the affiliation with the state where "Soviet" is replaced with "Russian". The relevance of the research is in 1) its critical interpretation of the modern Russian projects of supragroup identity, 2) its substantiation of the preference of constructing identity on the basis of shared culture, cultural space, not citizenship, 3) its substantiation of reliance on language as the basis for building a collective cultural identity.

The structure of the article includes analysis of the modern methodology of the ethnic identity studies and the existing approaches to understanding the supragroup (macrosocial) identity. Following this, a critical comprehension of the methodology is discussed in the context of sociophilosophical problems. Next, in the discussion section, we substantiate the importance of the "language factor" in the construction of a supragroup identity that is based not on the affiliation to the state but the development of cultural connections, the construction of positive development scenarios, and the unifying senses in the dialogue of cultures. In conclusion, the variant of the correlation of individual, group ('ethnic) and supragroup (linguistic) identities are described, depending on whether the language of the supragroup identity is the native language of an individual or the language of inter-ethnic communication.

\section{Methods}

The fate of Soviet ethnology, the unquestionable achievements of which are based on the principle of historicism and the use of the Marxist methodology, mainly reflects the processes that have taken place in socio-humanitarian knowledge, science and a scientific method in the 20thcentury.

AsM.A. Khrustalev argued :

...the presence of many heterogeneous and, in particular, isomorphic research approaches in the relevant scientific discipline is an undeniable symptom of the fact that its formation has not yet been completed (Khrustalev, 2002: 34).

It has to be however noted that this is evidenced by the absence of a dominant research method in modern ethnology.

It is entirely possible that the theory structures modern political practice, thereby creating the reality that it was intended to describe. Speaking from a platform for radical constructivism, S.V. Sokolovsky supposes that this was the role played by the Soviet theory of ethnos in the sphere of interethnic relations (Sokolovsky, 1997; Tishkov, 1989)

However, there are other positions on this point. For example, I.Yu. Zarinov writes that the discussion atmosphere at several SovietAmerican symposiums in the early 1980 s did not rule out the recognition of the methods of Soviet ethnology by the American scientists. I.Yu. Zarinov noted that historicism as the research of social phenomena in historical aspect was the most 
important advantage of the Soviet ethnology (Zarinov, 2000). This fully applied to national ethnography, for which, as was written by one of the founders of the Soviet theory of ethnos, an academician Yu.V. Bromley (1973), the historical approach was necessary for the analysis of the genesis and evolution of ethos, its dynamics as an organic, integral system. One of the most important directions of the ethnographic science - ethnic history - is connected with this research aspect; in the frame of this direction, the study of separate components of the ethnos is ultimately subject to the determination of its dynamics as an integrated system. The primary task of the development of problems of ethnic history is to study all types of ethnic processes, including ethnosocial ones (Bromley, 1973). As noted by I.Yu. Zarinov, today this quotation from the work of Yu.V. Bromley evokes an incredulous smile in domestic followers of constructivist approach in modern Russian ethnology because they do not consider both "ethnos" and "ethnic processes" as an objective reality. Russian constructivists do not accept a category of "ethnos", which, as already noted above, is the primary theoretical basis of Soviet ethnological science (Zarinov, 2000).

One has to note that the Soviet school of scientists who dealt with the whole complex of national problems is criticised from the different standpoints including constructivism. Thus, V.Yu. Zorin, a supporter of the transition from the civil supragroup identity to the ethnocultural one, supposes that the Soviet methodology of ethnic studies has exhausted its constructive potential and doesn't meet the challenges of our time (Zorin, 2003: 123).

Therefore, the fact that previously used concepts do not become entirely irrelevant should also be taken into account, but their adequacy in today's rapidly changing conditions of existence and study of ethnicity is not always complete. Besides, the growing specialisation in the scientific world leads to the fact that even specialists of related sciences hardly "understand" each other, and this also makes it difficult to apply proven methods and approaches in "related" sciences.

The very existence of "ethnicity" is not universally recognised. It should be remembered that the term "ethnicity" and the related concept were perceived by domestic ethnologists differently. As argued by I.Yu. Zarinov, "in post-Soviet ethnology, a number of scientists did not understand the necessity of perception of this concept", because an English-language term "ethnicity", which underlie the concept of ethnicity, had a lot of different definitions: from the need and ability of a group of people or an individual to identify themselves in society to the recognition of a set of objective features denoting ethnic (and sometimes even non-ethnic) community (Zarinov, 2000). The monograph of N.G. Skvortsov that was especially devoted to the problem of ethnicity in social anthropology indicated the absence of an integral view on the concept of "ethnicity" in the studies of Western scientists (Skvortsov, 1996).

Ethnological constructivism that denies both the principle of historicism and sometimes the ethnos is a dominant paradigm in modern Russian ethnology. Constructivists who claimed to be postmodernists in ethnology describe the ethnos as a social (politicised, informational) construct. The comprehension of ethnos as an imaginary community is significant (Anderson, 2006). It is characteristic that the ethnos acquire a postmodern interpretation in the "classical reality", where the criteria of truth are different from postmodern ones, that is, the ethnos as an objective phenomenon is investigated in the system that perceives any objectivity "with a grin", and the result is extrapolated into a system with directly opposite views. The constructivists "forget" to indicate that this focus is possible, for example, with regard to the state, and, with 
great success, to the natural-legal conception of law, on the basis of which such an important legal institute as the human rights' institute was established (Maiboroda \& Tsapko, 2008).

Peculiar "dialectics" of the list of human rights and freedoms and the phenomena of language and ethnos in the studied context consists in the fact that the right to speak native language is one of the most important rights in a number of rights and freedoms and simultaneously a personal and collective right. Many collective rights are also ethnicspecific, for example, the right of indigenous peoples to the land of original residence. The International Covenant on Economic, Social and Cultural Rights states: "All peoples may, for their own ends, freely dispose of their natural wealth and resources to achieve their goals ..." (Part 2 of Article 1 of the Covenant). Concerning indigenous peoples, the content of this right is sufficiently detailed in Convention No. 169 "Concerning Indigenous and Tribal Peoples in Independent Countries" adopted by the General Conference of the International Labor Organization on June 26, 1989.

Thus, to what extent the ethnos is a "constructed" phenomenon and ethnicity is objective - this is an issue, the final solution of which is prevented by the essence of the studied concepts. However, social reality is constructed indeed. As noted by M.N. Epstein, technologies in an attempt to approach the creation of artificial environment and artificial intelligence enter the sphere of the humanities. And what casts doubt on the scientific nature of the humanities - subject-object reversibility, semantic diffuseness, and language metaphoricity - is of the most significant interest for technical and natural sciences (Epshtein, 2004).

Perhaps, the "weaknesses" of the humanities offer opportunities not so much for actual knowledge, but for changing the reality knowledge transforms from reality-via descriptions to constructive knowledge. However, the potential possibility of reality construction makes it impossible to determine it within the binary opposition "truth-lie". This indeterminacy is now analysed within the framework of two primary research strategies that, with a certain degree of conditionality, can be designated as coping and subordination strategies.

Verificationism and falsificationism, as well as their predecessors, combined by I. Lakatos as "justificationism", have reflected the indeterminacy through methodological strategies implying the exit through demarcation, not acceptance. However, the final solution of the demarcation issue was put into question (for example, Duhem-Quine's thesis, etc.) and this process had the features of a self-reproducing process (Lakatos, 1995). However, we can talk as much as we can about the dispute of T. Kuhn and K. Popper on the level of importance of the rational principle or, on the contrary, of the enlightenment in scientific changes. However, half a century before the beginning of this dispute, rationalism as a theoretical basis and a rational argument as a form of communication in social relations were already condemned. The refusal to appeal to reason and rational principle in favour of the construction in the framework of techniques that later became known as the "engineering of consent", "crystallization of public opinion" is linked to E. Bernays' activities in advertising and public relations (Bernays, 2012; Bernays, 2013). In this context, it is important to note that the future "Thomas theorem" -describing "if men define situations as real, they are real in their consequences" $p$. 220)- appeared in 1927 as a sociologist's observation, but it was reflected in academic science by R. Murdoch only in 1982 (Lukov, 2006).

This is the representation of the methodology of science, but this is not a general representation of social sciences. While Karl Popper denies history and sociology as a science, they also serve as tools of the social construction of the future (ideological programs) and marketing in trade and politics (Popper, 2013). If the Vienna Circle set the task 
of developing a concept for verifying scientific truth through consistent empirical verification of "protocol statements" fixing the facts of "pure experience", then the representatives of the Frankfurt School developed theoretical bases for writing "songs of mass culture and youth protest". Conformity to the social reality has a powerful theoretical basis in the works of representatives of various directions of neoMarxism. At the same time, the methods of the humanities and social sciences are becoming more and more exposed to the effect of "feedback", following the relativism of truth. Myths of public consciousness and humanitarian knowledge are disproved within mythological thinking. Methodological indeterminacy becomes constant.

\section{Results}

We understand supragroup identity as an individual sense of belonging to a macrosocial community that does not exclude the group identity but complements it. It is a characteristic of identity that is derived from the group identity and is interconnected with it. The following pairs can be an example of a supragroup identity and its connection to a group identity: the supragroup identity of the French and the group identity of the Bretons, the supergroup identity of Europeans and the group identity of the French.

The construction of any supra-group identity in one way or another is a practice that consolidates groups and harmonises the processes of their interaction. At the same time, the construction of language supragroup identity, unlike civil identity, will be based on a more objective, historically developed factor - the factor of language, which is less situational than the element of the sovereignty of the state over a particular territory. It should be noted that this factor has not got those negative connotations that inevitably arise in the "personality-state" interaction.

We suppose that the Soviet project of nation construction did not take place mainly because it turned into the development of general civil identity, and it cannot exist without a powerful state, it painfully perceives all its failures, it cannot adequately level out ethnic contradictions, on the contrary, they become the most crucial group marker within a large state that constructs a "civil super-ethnos". One has to note that the first decades of Soviet "nation construction" were characterised by completely different processes: supra-group identity was formed in the plane of ideology, and the state was viewed as a stepping stone to the global community of labour masses freed from capitalist and colonial exploitation. The stage of the most successful development of national languages of the undivided USSR peoples took place in this period; national alphabets and the writing system were created, they began to translate the educational, scientific and fiction literature into the languages of the USSR peoples. The languages also transformed: "...the syntactic structure of languages was perfected, branched and flexible stylistic differentiation was created, and many stylistic variations appeared for the first time" (Filin, 1966: 33).

Thus, the construction of supra-group identity should not be "tied" to the state, but, if possible, it should be of "super-ethnic construction" nature when the constructed super-ethnos is understood as a culturalhistorical community with such objective characteristics as, first of all, common language, common values, everyday legal consciousness and legal culture.

Apparently, the construction of supra-group identity is hardly possible in the situation of recognition of groups to be consolidated as imagined communities (Anderson, 2006). This refers to "recognition" not in the language of social sciences, but recognition in the language and goals of consolidating practices. Recognition of reality does not necessarily lead to "cementing" of group identity. Another thing is that this recognition cannot be based on an uncritically accepted set of group representations about itself and other groups. The selection of identity characteristics is impossible without a critical 
rethinking of "national memory": it is necessary to reject negative stereotypes and established characteristics stigmatising the "other". The reality of the ethnos will actually become the actual reality in a possible world of construction of supra-group identity harmonising inter-group relations.

Ethnicity and ethnic identity will develop within supra-group language identity as a strategic goal, in a sense, a meta-goal of the project, combining value, behavioural, and cultural attitudes. Successful construction of supra-group identity will inevitably transform ethnicity and ethnic stereotypes, removing inter-group contradictions to a certain extent, harmonising inter-group relations.

\section{Discussion}

Ethnicity, a marker deterministic both concerning an individual and to a group, is not, however, the only (and in the paradigm of constructivism - it is not the most important) distinctive group feature. Ethnicity as a marker acquires significance regarding disassembly of a traditional state that loses its ability to maintain and reproduce nation-wide identity. Summarising the most essential characteristics of this process, we can conclude that there are objective contradictions between a new information phase of civilization development, one of the conditions for the transition to which is the construction of a transnational community (Globalization Project and alternative globalization projects), and the previous phase - an industrial one, the adequate functioning of which is inextricably linked to the presence of a powerful administrative apparatus that is ultimately enhanced for a socio-economic system in the form of a modern democratic legal state. The characteristic - "democratic" means the presence of "feedback" of the administrator and the population, "legal" means minimisation of the level of chaos in the system by introducing general "rules of the game" - legal principles and standards.
Only such state could adequately support general civil identity in various forms (a nation-state where the issue was solved through the formation of a nation, a multiethnic state, where the problem was solved through the civilian "superstructure" (the Soviet people in the USSR - a "melting pot" in the USA)), or in certain forms of "imperial projects", or under one denomination, or based on projectivity built around a super-ethnos (Pan-Slav, Pan-Arab, Pan-Turkic projects). It means the significance of the state was so crucial that civil (or coherent to it - religious) identity was more attractive than ethnic identity. It was a kind of ethnicity "overcoming" - its transition into a more general civil form and this was the birth of national states and "imperial projects".

Nowadays, ethnicity as a somewhat stable marker of differentiation "goes to the forefront" of confronting the homogenising power of globalisation as a process of integration and unification in the spheres of economics, politics and culture that affects ethnic identity and other types of identity. In the language of the media and largely in the language of social sciences, this process is identified with the opposition of archaic survivals to the achievements of humanism and progress. In the ongoing "change of systems", the resistance will tend to be commensurate with the degree of impact, and unifying practices will counter decentralist practices. And, unfortunately, at a certain stage, the disassembly of "major fragments" will correspond both to the logic of globalisation and the interests of many ethnic communities (at least, at the level of ethnic elites). Thus, the pressure on the state will be imposed in an "in-and-out" way. We think this allows speaking about the impasse of modern projects of "general civil identity" and the challenges of constructing the identity that is not tied to the state, that may step over the borders of the state and be a conductor of its so-called "soft power" (Tsapko, 2017). 
In this regard, an opinion of J. Nye, an author of the "soft power" concept, is also of interest - analysing the attempts of Russia and China to apply this technology, he was skeptical enough about the direct involvement of the state in the promotion by using "soft power" methods (Nye, 2013).

Therefore, the central task is to determine the underlying substance of identity construction - a substance which is real and mediates reality, serves both as a medium and a message (McLuhan \& Fiore, 1967), may overcome political boundaries and is not associated with the state. We suppose this substance is language. The importance of communication in philosophy and methodology of science has been reinterpreted in the framework of logical positivism. In linguistics, this process took place in the context of neohumboldtianism and mainly within the hypothesis of the linguistic relativity of $\mathrm{W}$. Sapir and B. Whorf. Generally speaking, the main idea of the explanation of linguistic relativity can be formulated as follows: "...reality does not determine the language spoken, but, on the contrary, every time our language divides reality in a new way. Reality is mediated by language" (Zvegintsev, 1960: 111; Whorf, 1960). The importance of language and language identity in the system of the formation of a unifying identity is determined by the fact that in many modern paradigms of the humanities (and both in the framework of poststructuralism and postmodernism) language appears as a phenomenon not mediated but mediating reality. Consequently, language identity is the space for the construction of paradigms of ethnicity understanding, the space for the formation of unifying values.

The hypothesis of linguistic relativity played a significant role in the development of the humanities, especially in interdisciplinary cultural studies. Further, an idea appeared in the philosophy of postmodernism that every text does not reflect reality, but creates a new reality, instead, a variety of new facts.
However, it can be assumed that, despite the attitude of postmodernists to truth and reality, postmodernism emerged objectively as a philosophical reflection of the phase civilizational transition from industrial society to an information society. The pluralism of truth in the postmodern worldview reflects the growth of chaos and entropy in the system at the phase transition point. Accordingly, it will inevitably give way to new, transformative and harmonising paradigms.

\section{Conclusion}

Language identity underlying the construction of supra-group identity will initially entail the creation of two types of identities. The first type includes a local native language and a supra-group language - a language of intergroup (interethnic) communication. The second type comprises native and supragroup languages - this is the same language of an individual. This will require particular attention to the array of local languages, their preservation, and development. And this will be a prerequisite for project viability. Ethnicity and ethnic identity will develop within supra-group language identity as a strategic goal, in a sense, a meta-goal of the project, while value, behavioural and cultural attitudes will be harmonised. The successful construction of supra-group identity will inevitably transform ethnicity harmonising interethnic relations, although it is clear that transformation will never be over.

\section{References}

Anderson, B. (2006). Imagined Communities. London, New York: Verso.

Bernays, E. (2012). Manipulyatsiya obshchestvennym mneniem: kak i pochemu [Manipulation of public opinion: How and why]. Polis. Politicheskie issledovaniya, 4, 149-159.

Bernays, E. (2013). Inzheneriya soglasiya [Engineering of consent]. Polis. Politicheskie issledovaniya, 4, 122-131. 
Bromley, Yu.V. (1973). Etnos i etnografiya [Ethnos and ethnography] (p. 237). Moscow: Nauka.

Epshtein, M. (2004). Znak probela: O budushchem gumanitarnykh nauk [Space mark: On the future of the humanities]. Moscow: Novoe literaturnoe obozrenie.

Filin, F.P. (1966). Nekotorye voprosy razvitiya yazykov narodov SSSR [Some problems of the development of the languages of USSR peoples]. Vestnik AN SSSR, 11, 33.

Khrustalev, M.A. (2002). Politologiya i politicheskii analiz [Political science and political analysis]. In A.D. Bogaturov, N.A. Kosolapov, \& M.A. Khrustalev, Ocherki teorii $i$ politicheskogo analiza mezhdunarodnykh otnoshenii [Essays on the theory and political analysis of international relations] (p. 34). Moscow: Nauchno-obrazovatelnyi forum po mezhdunarodnym otnosheniyam.

Lakatos, I. (1995). Falsifikatsiya i metodologiya nauchno-issledovatelskikh programm [Falsification and methodology of research programs]. Moscow: Medium.

Lukov, A.V. (2006). Sledstviya "teoremy Tomasa" v usloviyakh stanovleniya informatsionnoi tsivilizatsii [Consequences of the "Thomas Theorem" in the conditions of information civilization]. Znanie. Ponimanie. Umenie, 4, 220-222.

Maiboroda, E.T., \& Tsapko, M.I. (2008). Yazykovaya identichnost kak uslovie obespecheniya informatsionnoi bezopasnosti $v$ sfere mezhetnicheskikh otnoshenii [Language identity as a condition for ensuring information security in the sphere of interethnic relations]. In Aktualnye problemy sotsiogumanitarnogo znaniya: Sbornik nauchnykh trudov [Topical problems of socio-humanitarian knowledge: Collection of scientific works] (Issue 17, pp. 127-130). Moscow: Vek knigi-3.

McLuhan, M., \& Fiore, Q. (1967). The Medium is the Massage: An Inventory of Effects. New York: Random House.

Nye, J.S. (2013, 29 April ). What China and Russia Don't Get about Soft Power. Available at: http://foreignpolicy.com/2013/04/29/whatchina-and-russia-dont-get-about-soft-power/ (accessed July 16, 2017)

Popper, K. (2013). Logik der Forschung. Berlin: Akademie Verlag $\mathrm{GmbH}$.

Skvortsov, N.G. (1996). Problema etnichnosti v sotsialnoi antropologii [The Problem of ethnicity in social anthropology]. St. Petersburg.

Sokolovsky, S.V. (1997). Menshinstva v rossiiskikh regionakh: otechestvennaya etnografiya i politicheskaya praktika [Minorities in Russian regions: National ethnography and political practice]. In Etnometodologiya: problemy, podkhody, kontseptsii (sbornik statei) [Ethnomethodology: Problems, approaches, concepts (Collection ofarticles)] (Issue 4, pp. 82-100). Moscow: Put.

Tishkov, V.A. (1989). O novykh podkhodakh v teorii i praktike mezhnatsionalnykh otnoshenii [On new approaches in the theory and practice of interethnic relations]. Sovetskaya etnografiya, 5, 8.

Tishkov, V.A. (2017). Chto est natsiya: V poiskakh rossiiskoi identichnosti [What is a Nation: In search of Russian identity]. Nezavisimaya Gazeta, available at: http://www.ng.ru/stsenarii/2017-0124/9_6910_nacia.html (accessed July 16, 2017). Tsapko, M.I. (2017). Yazykovaya identichnost kak obedinyayushchaya identichnost: $v$ poiske konstruiruyushchikh metodologicheskikh strategii [Language identity as unifying identity: In the search for constructing methodological strategies]. Language and culture in the era of integration of scientific knowledge and professionalization of education. Proceedings of the International Scientific and Practical Conference, Russia, Pyatigorsk, 16-17 March 2017.

Whorf, B. (1960). Otnoshenie norm povedeniya $i$ myshleniya $k$ yazyku [The Relation of standards of behavior and thinking to language]. In Novoe $v$ lingvistike [New in linguistics] (Issue 1). Moscow. 
Zarinov, I.Yu. (2000). Vremya iskat obshchii yazyk: Problema integratsii razlichnykh etnicheskikh teorii i kontseptsii [Time to bearch for a common дanguage: The problem of integration of various ethnic theories and concepts)]. Etnograficheskoe obozrenie, 2, 4.

Zorin, V.Yu. (2003). Ot natsionalnoi politiki k etnokulturnoi: Problemy stanovleniya doktriny $i$ praktiki (1990-2002 gg.) [From national to ethno-cultural politics: The problems of the development of doctrine and practice (19902002)]. Zhurnal sotsiologii $i$ sotsialnoi antropologii, 6(3), 123.

Zvegintsev, V.A. (1960). Teoretikolingvisticheskie predposylki gipotezy SepiraUorfa [Theoretical and linguistic prerequisites of Sapir-Whorf hypothesis]. In Novoe $v$ lingvistike [New in linguistics] (Issue 1, pp. 111134). Moscow. 